\title{
"PUBLIC RELIGION" AND THE PANCASILA-BASED STATE OF INDONESIA: A Theological-Ethical Analysis ${ }^{1}$ Benyamin F. Intan \\ International Reformed Evangelical Seminary, Jakarta
}

\begin{abstract}
Kehadiran agama dalam ruang publik merupakan suatu keniscayaan. Hal itu terkait misi agama-agama untuk menghadirkan perdamaian sebagai kontribusi positifnya. Walau pada dirinya agama itu juga mengandung dua potensi paradoks, yaitu menumbuhkan kekerasan disatu pihak, dan rekonsiliasi dipihak lain, namun revitalisasi agama publik bisa mengikis peranan negatif agama untuk kemudian memaksimalkan peran positif agama-agama itu.

Carut marutnya wajah agama publik di Indonesia jelas merupakan suatu anomali, khususnya akibat kekerasan negara terhadap agama. Keputusan founding fathers bahwa Indonesia bukan negara sekular seharusnya membebaskan agama dari belenggu untuk hanya ada pada ruang privatnya, sedang penetapan Indonesia bukan negara agama, mensyaratkan tempat terhormat bagi agama. Karena itu pemerintah tidak hanya berkewajiban menjamin kebebasan beragama, tapi juga mendorong pertumbuhannya, dengan demikian jelaslah hegemoni agama adalah suatu absurditas, dan tidak memiliki akarnya di negeri ini. Sebaliknya agama publik harus dikembangkan untuk menjadi tempat dimana peran publik agama-agama diakui dan dikembangkan.
\end{abstract}

KeY WoRDS: Agama, ruang publik, agama publik, ruang privat, kekerasan.

1 Part of this article has been published at God's Fiery Challenger for Our Time, Benyamin F Intan, ed. (Jakarta: STEMI and Reformed Center for Religion and Society, 2007), pp. 487-507; another part of this article has been published at Reform Review: Jurnal untuk Kajian dan Pemetaan Krisis vol. I, no. 1 (April-June 2007): pp. 6-12; and another part has been presented at a panel discussion on pluralism in religion, in cooperation with the Asian Foundation and Pusat Studi Islam and Kenegaraan (PSIK) Universitas Paramadina on October 10th at Hotel Dharmawangsa, Jakarta. 


\section{Introduction}

As the Cold War came to an end, many thinkers declared the triumph of secular liberal democracy. Humanity, according to Francis Fukuyama, had reached the "end of history" and its endpoint was secular liberal democracy, "the best possible solution to the human problem"- - the best political system humans could achieve. ${ }^{2}$

The rise of religious traditional movements from all over the world in the late 1980s and early 1990s, however, belies that assertion. From political Islam to Catholic liberation theology, these religious movements have begun pushing themselves out of the private realm and into public life. These religious movements are united, as Mark Juergensmeyer has put it, "by a common enemy-Western secular nationalism - and a common hope for the revival of religion in the public sphere." 3 This public role of religion has a global relevance. It appears not only in non-Western countries, where religion and tradition are still very strong, but also in Western countries in which the democratic tradition has been longstanding. ${ }^{4}$

To put it differently, since the end of the Cold War religion has become one of the most important forces in international politics, for better or worse. It has been argued that the manifestation of religion in the public sphere may give rise to conflicts and may deepen social divisions. Casanova, for example, notes that during the entire decade of the 1980s, it is almost impossible to find any serious political conflict around the world that does not contain behind it the "hand of religion."

In the Middle East, all the religions and fundamentalisms of the region-Jewish, Christian, and Muslim_fed by old power struggles, were meeting each other in civil and uncivil wars. Old feuds between the various world religions and between branches of the same religions were flaring up again from Northern Ireland to Yugoslavia, from India to the Soviet Union. ${ }^{5}$

The title of a book by Gilles Kepel describes the history of modern revivalist movements in Judaism, Christianity, and Islam as The Revenge of God. ${ }^{6}$ It analyzes the Ayatollah Khomeini's Islamic revolution in Iran, the Israelite militant Zionism of the Gush Emunim, the highly politicized Catholic lay movement in Italy, and the Moral Majority sponsored by

\footnotetext{
2 Francis Fukuyama, The End of History and the Last Man (New York: Avon Books, 1992), p. 338.

3 Mark Juergensmeyer, The New Cold War? Religious Nationalism Confronts the Secular State (Berkeley and Los Angeles: University of California Press, 1994), p. 4.

4 Jose Casanova, Public Religions, p. 10. To illustrate the various forms of deprivatization available to different religious bodies, Casanova provides five case studies and two of them take place in the United States where the democratic tradition has been longstanding. See Casanova, Public Religions, pp. 135-207.

5 Casanova, Public Religions, p. 3.

6 Gilles Kepel, The Revenge of God: The Resurgence of Islam, Christianity and Judaism in the Modern World (University Park: The Pennsylvania State University Press, 1994).
} 
Protestant fundamentalism in the United States. Kepel argues that all these movements call people to return to God and to reject secularization and modernism. The conflicts between "religionists" and "secularists," according to Juergensmeyer, hold the potential for violent confrontation, leading to what he calls a new Cold War. ${ }^{7}$

Portrayals of religion as violent and intolerant are not a complete picture of religion, however. Casanova argues that during the 1980s, religious activists were also major players in movements striving for liberation, justice, and democracy around the world.

Liberation theologies were spreading beyond Latin America, acquiring new forms and names, African and Asian, Protestant and Jewish, black and feminist. With the collapse of socialism, liberation theology seemed the only "International" that was left. ${ }^{8}$

R. Scott Appleby has underlined many contemporary religious movements with the same agenda of promoting justice, tolerance, and peace. ${ }^{9}$

From the discussion above, we may conclude that religion has a dual impact or what Appleby calls an "ambivalence of the sacred." Exploring the histories of Christianity, Judaism, Islam, Hinduism, and Buddhism, Appleby argues that each religious tradition contains seeds for violence as well as reconciliation. ${ }^{10}$ This dual impact of religion, according to Casanova, has been influenced to some extent by "the Janus face" of religion, which tends to be "exclusive, particularist, and primordial" on the one hand, and rich with "inclusive, universalist, and transcending [identities]," on the other hand. ${ }^{11}$ Regardless of this dual-face of religion, one lesson becomes clear in these and other studies: $:^{12}$ religion will continue to play a significant role in the modern world.

This article is based on the assumption that an optimism for public religion as a democratic power in Indonesia is viable. Based on the existing facts, I will first map out the problems and challenges that public religion in Indonesia has faced in transforming the social-political life of society. I will subsequently examine the development prospect of public religion, namely, what it should do in order to perform as a transforming power in the creation of a democratic political life. I will conclude by explicating the descriptive and prescriptive actions that public religion should take - what is and what ought to be, the indicative and the imperative - from the

\footnotetext{
7 Juergensmeyer, The New Cold War?

8 Casanova, Public Religions, p. 3.

9 See R. Scott Appleby, The Ambivalence of the Sacred: Religion, Violence, and Reconciliation (Lanham: Rowman \& Littlefield Publishers, Inc., 2000), pp. 121-65, 245-80.

10 See Appleby, The Ambivalence of the Sacred.

11 Casanova, Public Religions, pp. 3-4.

12 See, for example, Juergensmeyer, The New Cold War, Mark Juergensmeyer, Terror in the Mind of God: The Global Rise of Religious Violence (Berkeley: University of California Press, 2000), Kepel, The Revenge of God.
} 
theological-ethical viewpoint. The analysis will focus on how these two entities can be reconciled without being trapped in utopian discourse on the one hand and hopeless realism on the other.

\section{The Definition of "Public Religion"}

With the flood of globalization, the latest development of religion shows that the steps it has taken at the public sphere is inevitable. The validity of conventional secularization theories initiated by Karl Marx, Auguste Comte, Herbert Spencer, Emile Durkheim, Max Weber, and Sigmund Freud, claiming that secularization brings religious decline in the modern world (secularization as religious decline), are to be questioned.

History has proven that since World War II, with some exceptions like in Western Europe, the growth of religion in the remote parts of the world has soared, and there is no holding it back. ${ }^{13}$ This leap of growth has occurred even in modern societies such as the United States. Christianity's decline in Western Europe was caused not by the wave of modernism but rather by the existence of an absolute Christian state (the caesaropapist state church). This kind of religious state was paradoxically counter-productive for Christianity, as Alexis de Tocqueville has observed since 1985 and elucidated in his magnum opus, Democracy in America,

The church cannot share the temporal power of the state without being the object of a portion of that animosity which the latter excites....[Due to] the close connection of politics and religion [t]he unbelievers of Europe attack the Christians as their political opponents rather than as their religious adversaries; they hate the Christian religion as the opinion of a party much more than as an error of belief; and they reject the clergy less because they are the representatives of the Deity than because they are the allies of government. $^{14}$

Unlike Western Europe, the U.S. has never had a caesaropapist state church. ${ }^{15}$ The rapid growth of religion in the U.S. leads Casanova to the conclusion that modern differentiation triggers the growth of religion instead of hindering it. ${ }^{16}$ In short, the thesis secularization as religious decline has suffered bankruptcy and lost its prestige in the sociologists' circle. Peter Berger, for instance, who initiated this theory in the 1950s and 1960 s, ${ }^{17}$ now considers it "essentially mistaken, ${ }^{, 18}$ Rodney Stark and Roger

\footnotetext{
13 See Frank Whaling, ed. Religion in Today's World: The Religious Situation of the World from 1945 to the Present Day (Edinburgh: T \& T Clark, 1987).

14 Alexis de Tocqueville, Democracy in America (New York: Everyman's Library, 1994; reprint, fourth), pp. 310, 14.

15 Whaling, Religion in Today's World, p. 29.

16 Casanova, Public Religions in the Modern World, pp. 26-7.

17 Peter L. Berger, "Protestantism and the Quest for Certainty," Christian Century 115, no. 23
} 
Finke even suggest discarding the outdated theory. ${ }^{19}$

The secularization theory initiated by Thomas Luckmann ${ }^{20}$ and Niklas Luhmann ${ }^{21}$ that marginalizes religion to a private sphere (secularization as privatization), suffered the same fate. Shifting religion away from the public sphere means the same as trivializing it (pengkerdilan agama), which will result in a terror-spreading radical religion movement. As David Hollenbach says,

For where religion becomes a private preference alone, public life lacks the depth of meaning that can generate loyalty and commitment among citizens. The resulting anomie can create a vacuum into which fundamentalist forces insert themselves, almost certainly without civility and possibly with violence. ${ }^{22}$

The rise of religion which has invaded public sphere and left its private territory, questioning and accusing regimes in Spain, Poland, Brazil, and the U.S., has to be viewed as a resistance to trivialization efforts. According to Douglas Johnson and Cynthia Simpson, religion is no longer "the missing dimension of statecraft." ${ }^{, 3}$ Whatever happens, religion will not return to its origin: a mere private matter without having a social-political role. Therefore, the thesis secularization as privatization has lost its relevance.

This condition of religion as a point of no return has caused Casanova to change the definition, "public religion", to "the deprivatization of religion," which means that religion is no longer confined to its private sphere. ${ }^{24}$ The deprivatization of religion has an ontologically normative framework: its presence is no more than simply a fact that has to be accepted (das Sein), yet it must exist - it is something that cannot be done without (das Sollen). That means, the deprivatization of religion is not just a reaction against trivializing religion or a question of whether there is a challenge of marginalization. Public domain is still an inherent, inseparable

\footnotetext{
(1998): p. 782.

18 Berger, "The Desecularization of the World: A Global Overview," in The Desecularization of the World: Resurgent Religion and World Politics, Peter L. Berger, ed. (Washington D.C. and Grand Rapids: Ethics and Public Policy Center and William B. Eerdmans, 1999), p. 2.

19 See Rodney Stark dan Roger Finke, Acts of Faith: Explaining the Human Side of Religion (Berkeley: University of California Press, 2000).

20 See Thomas Luckmann, The Invisible Religion: The Problem of Religion in Modern Society (New York: Macmillan, 1967).

21 See Niklas Luhmann, The Differentiation of Society, trans. Stephen Holmes and Charles Larmore (New York: Columbia University Press, 1982).

22 David Hollenbach, "Fidelity to the Gospel/Respect for the Other," in Faith in the Public Forum, Neil Brown and Robert Gascoigne, eds. (Adelaide: Australian Theological Forum, 1999), 4. See also Kepel, The Revenge of God, pp. 4-5.

23 Lihat Douglas Johnston and Cynthia Sampson, eds. Religion, the Missing Dimension of Statecraft (New York and Oxford: Oxford University Press, 1994).

24 Casanova defines "deprivatization" as "the fact that religious traditions throughout the world are refusing to accept the marginal and privatized role which theories of modernity as well as theories of secularization had reserved for them," see Casanova, Public Religions in the Modern World, p. 5.
} 
part of religion.

On the other hand, it is most regrettable that the resistance to the privatization of religion is accompanied by "backlash", 25 and "revenge" is the motivation behind it. ${ }^{26}$ As a result, the revitalization of religion has swung from one extreme to the other like a pendulum, turning unbridled and uncontrolled. Religion's active participation such as in power politics to revenge itself is ineffective. More than that, it tears down its own image, such as in extreme cases where religion has been used to legitimatize violent terrorist acts.

Therefore, in order to steer clear of counter-productive effects in the deprivatization of religion, boundaries must be set. Although Casanova rejects the theses of secularization as religious decline and secularization as privatization, it does not mean that the theory of secularization is no longer feasible. Casanova is convinced that differentiation can accelerate the process of democratization in religion. It inspires him to offer the concept of secularization as differentiation, in which the spheres of religion and the secular are differentiated, thus making it applicable at the "public religion" level. Differentiation as the core of modern structure implies separation of public life elements - each entity such as the state, economics, science and education is to have its own autonomy and institution. ${ }^{27}$

Although both differentiation and absolute separation have the element of separation in them, they are not the same. The idea of absolute separation pushes religion away from the public sphere. John Rawls, who shares this view, argues that conflict among religions which aims at a horizontal conflict is often caused by the incapability of religion to accept diversity as a fact (what is), or what he calls "the fact of pluralism." In Rawls' opinion, the incapability to accept pluralism as a fact will destroy it, while destroying pluralism also means destroying democracy. Thus, Rawls is determined to save pluralism in religion, which he believes to be something that can never be settled in the public sphere. Rawls suggests that every religion should restrain itself and be considerate, using "the method of avoidance," braving the possible consequence of being pushed away from public. According to Rawls, the public domain has to remain neutral, not to be distorted by religious values. ${ }^{28}$

Consequently, religion is marginalized to the private domainstunted and shackled, to be used at will by the state. Religion will lose its transcendental power if it is manipulated by political control. Stripping religion off its transcendent identity cripples it, making it no longer critical

\footnotetext{
25 Intan, "Public Religion” and the Pancasila-Based State, p. 7.

26 See Kepel, The Revenge of God: The Resurgence of Islam, Christianity and Judaism in the Modern World (University Park: The Pennsylvania State University Press, 1994).

27 Casanova, Public Religions in the Modern World, p. 7.

28 John Rawls, "The Idea of an Overlapping Consensus," Oxford Journal of Legal Studies 7 (1987): pp. 1, 4, 12-13.
} 
and prophetic, unable to preserve the morality of the state. Religion will then be shrunk, serving simply as a political commodity, a tool for legitimizing the power of the state. Ultimately, the politicization of religion (politisasi agama) - the subordination of religion by the state-will be inevitable.

Unlike absolute separation, the idea of differentiation gives religion the freedom to voice its moral conscience in public. Religion as public morality neither claims to be the one and only solution nor demands all social facts to submit to it. Secularization as differentiation never attempts to "religionize politics" (subordinating all public entity, including the country's territorial, under the power of religion). Doing that will cause the state to lose its noble function which is to protect its citizens and treat them justly and with no discrimination. Thus, secularization as differentiation rejects both discourses: the subordination of religion by the state in the form of politicization of religion and vice versa, the subordination of the state by religion in the form of religionization of politics (agamaisasi politik).

The question now arises as to where the position of the "deprivatization of religion" at public sphere is located ${ }^{29}$ in order that it may become a liberating power for a democratic political life. Casanova's case study in four countries (Brazil, Spain, Poland, and the U.S.) concludes that the dispute of religion about establishing a theocratic state at public sphere is not at a state level discourse. It is not at a political society level by establishing a religious political party either, but at a civil society discourse.$^{30}$ Casanova is convinced that as long as its activities are on civil society level, religion can be conciliatory and transformative in the process of the nation's democratization.

29 Concerning the public role of religion, a definition of public itself is needed. "Publicity," according to William Johnson Everett, "embraces all the activities that go into the creation of public life....It is an activity in which people profess their convictions and search for agreement about their common life. Indeed, they have to express their convictions honestly in order to search for agreements that will rest on genuine commitment and mutual trust," see William Johnson Everett, Religion, Federalism, and the Struggle for Public Life: Cases from Germany, India, and America (New York: Oxford University Press, 1997), p. 13. The definition of publicity which is strongly influenced by Hannah Arendt, John Dewey, and Jürgen Habermas drove Everett to the conclusion that res publica (public affairs) has four main characteristics: participation, plurality, persuasion, and commonality. Without these four elements, the role of public religion becomes stunted and unproductive. See also William Johnson Everett, God's Federal Republic: Reconstructing Our Governing Symbol (New York: Paulist Press, 1988), pp. 54-62, 129-44.

30 Casanova, Public Religions in the Modern World, pp. 218-221. In Casanova's analysis, "deprivatization of religion" at the social order of civil society is not only applied on Christianity and the western world, but also includes non-Christian religions and non-western societies, Casanova, Public Religions in the Modern World, p. 10. 


\section{The Face of "Public Religion" in the Pancasila-based State of Indonesia}

The role and place of religion in the Indonesian context are as old as the republic itself. Prior to Indonesia's independence an intense discussion took place regarding the nature of the state: should Indonesia become a secular state, or a religion-based state (in this case it would be an Islamic state, since Islam is the majority's religion)? The decision was then made that Indonesia would neither be a secular nor a theocratic state, but a Pancasila-based state. ${ }^{31}$

Being a non-secular state means that Indonesia acknowledges the role of religions in the life of the nation. Confining religion to the narrow space of the private sphere is therefore not legitimized by the law. On the other hand, being a non-theocratic state implies that religion has no right to control the state. Nevertheless, the state acknowledges the social role of religion, since the various religions in Indonesia had made a significant contribution to the nation's fight for independence. Moreover, Indonesians are religious people. The declaration of Indonesia as a non-theocratic state in no way trivializes religion. On the contrary, it is the prerequisite for an honorable position for religion. The state not only preserves religious life but also encourages its growth, thereby confirming that no religious hegemony exists in Indonesia.

Pancasila is therefore highly compatible with the secularization as differentiation pattern, rejecting both the idea of a secular or a theocratic state. A Pancasila-based state not only ensures freedom of expression for religions, but also stimulates the political and social role of religion in the public sphere. In relation to this, the exceptional character of the first principle of Pancasila, "The Principle of One Lordship," has to be enhanced. In my opinion, the first principle has become the legitimating factor for the existence of public religion in Indonesia. The first principle is not only the acknowledgement of pluralism in religion an sich, or, in David Hollenbach's term, "a negative immunity." Actually, the second, third, fourth or fifth principle of Pancasila should be adequate to ensure pluralism and tolerance in religion. The telos of the first principle tends to encourage religions to play in their public role in the nation's social-political life - it is

\footnotetext{
31 Pancasila is Indonesia's national ideology. The word Pancasila is derived from Sanskrit and Pali: panca means "five," and sila means "foundation," "base," "pillar," "guideline." See J. Verkuyl, Contemporary Mission: An Introduction (Grand Rapids: William B. Eerdmans, 1987), p. 383. The five principles of Pancasila include: (1) The Principle of One Lordship (Ketuhanan Yang Maha Esa); (2) A Just and Civilized Humanity (Kemanusiaan Yang Adil dan Beradab); (3) The Unity of Indonesia (Persatuan Indonesia); (4) The Principle of Peoplehood Guarded by the Spirit of Wisdom in Deliberation and Representation (Kerakyatan yang dipimpin oleh Hikmat Kebijaksanaan dalam Pemusyawaratan/Keadilan); (5) Social Justice for all Indonesian citizens (Keadilan Sosial bagi Seluruh Rakyat Indonesia).
} 
what Hollenbach calls the "positive immunity" of freedom in religion. ${ }^{32}$

In the course of history the important role of religion often changes. Religion is sometimes privatized. On other occasions it tries to control the state, either by violence or by imposing religious values into laws and regulations to the extent that it creates religious discrimination. According to J. Soedjati Djiwandono, the tug of war between the position of religion at the public sphere and the state is due to the ambiguity of the statement, "not a theocratic state, but not a secular state either." ${ }^{33}$ In a more positive tone, T.B. Simatupang comments that the declaration of Indonesia as being neither a theocratic nor a secular state has never happened before in the history of mankind, and is therefore not easy to put into practice. ${ }^{34}$

There is no doubt that the bloody conflicts in Ambon and Poso were not related to religion in any way. They were actually the result of religion's politicization, in which religion was dragged onto the public domain to be made a symbol and a method of group resistance and solidarity. On the other hand, the politicization of religion which demands the single role of a certain religion as the only solution has been going on since the Reformation. All of this makes religion, which should bring peace in people's lives, often appear horrifying.

Robert W. Hefner is right in stating that in Indonesia the occurrence of violence related to religion is caused by the state and religion taking advantage of each other (politicization of religion and religionization of politics). ${ }^{35}$ This condition restricts the role of religion at the public sphere and renders it unable to strive for the good of the country. The question is how religion could be restored to its rightful position in the Indonesian context, since once this is done, its role in social life can be maximized. Is it realistic to set such a hope? And accordingly, what demands have to be fulfilled? The following discussion on "problem mapping" and "the development prospect" of public religion in Indonesia will try to answer these questions.

\footnotetext{
32 Detailed explanation of negative and positive immunity, see David Hollenbach, "Public Reason/Private Religion? A Response to Paul J. Weithman, ”Journal of Religious Ethics 22, no. 1 (1994): p. 42.

33 J. Soedjati Djiwandono, Setengah Abad Negara Pancasila: Tinjauan Kritis Ke Arah Pembaruan (Jakarta: Centre for Strategic and International Studies, 1995), hlm. 63.

34 T.B. Simatupang, Membuktikan Ketidakbenaran Suatu Mitos: Menelusuri Makna Pengalaman Seorang Prajurit Generasi Pembebas Bagi Masa Depan Masyarakat, Bangsa dan Negara (Jakarta: Pustaka Sinar Harapan, 1991), hlm. 236-7.

35 See Robert W. Hefner, "Islamizing Java? Religion and Politics in Rural East Java," Journal of Asian Studies 46 (1987): pp. 533-554.
} 


\section{Problem mapping of "Public Religion" in Indonesia}

Since their entrance and expansion prior to the birth of the Indonesian republic, the main problem of the various religions in Indonesia could be attributed to the state restricting them to their own private sphere (the politicization of religion). The state's domination of religion by putting a stronghold on the private domain of religion not only confines it, but also provokes it to take revenge by trying to control the state and creating terror-spreading radical movements all over the country. The state's politicization of religion in the form of religion's subordination by the state has become a boomerang and stirs up rejection against it. Hollenbach calls it a certainty which is "normatively objectionable". ${ }^{36}$

The other side of the coin, the religionization of politics, in attempting to put the state under the subordination of religion, neutralizes the state's noble function as its citizens' non-discriminating guardian. Moreover, it has a negative impact on religion itself and destroys the long lasting harmonious relationship between religions in Indonesia.

Any religion which offers itself as the only solution of the nation's problems by subordinating the state under its power (the religionization of politics) is actually a religion which tries to manipulate the state's decisions by taking them under its regulations. In this case, religion is the determiner in the treatment of the citizens of the state. If a state segregates its citizens based on their religion, it has in fact lost its most noble function as a nondiscriminating guardian for the good of its citizens. The inclusive and nonsectarian nature now becomes authoritarian and discriminative.

On the other hand, a religion that subordinates the state under its power in order to establish a theocratic state is a religion which claims its infinite self to be equal with the temporal and mortal power of the state. Such a religion has lost its transcendental characteristic. Without a transcendent identity, religion is crippled; it no longer functions critically and prophetically. As a result, it ceases to carry out its mission as the guardian of the state's morality.

In brief, the element of politicization of religion and religionization of politics contained in the concept of religion criminalization has actually become a suicidal move for all related parties.

It is unfortunate that the privatization of religion in Indonesia, which later on arouses a spirit of vengeance, happens not only due to the misuse of the state's authority; the religions themselves have their share in causing this vengeful spirit. For the sake of its bare existence, religion corrupts itself by joining forces with the absolute power. Religion's vengeful spirit is directed not only to the state by trying to show off its domination, but also

36 Hollenbach, "Politically Active Churches: Some Empirical Prolegomena to a Normative Approach," in Religion and Contemporary Liberalism, Paul J. Weithman, ed. (Notre Dame: University of Notre Dame Press, 1997), 301. 
towards other religions which demand their hegemony in the name of the state.

The establishment of the Religion Department on January 3, 1946, as a concession towards the rejection of the Jakarta Charter (Piagam Jakarta) ${ }^{37}$ is evidence of the politicization of religion which results in religious discrimination. The government's concession in facing the Dutch military aggression was made to obtain Moslem support as the majority religion. It shows the government's lack of consistency in being loyal to the Pancasila. The government has elevated Islam to be a privileged religion. Initially, the Religion Department only dealt with one religion, Islam. The concession, which was in reality a conspiracy, at the same time also shows that there was a religionization of politics, claiming the dominion and hegemony of Islam.

Later on, the Religion Department expanded its jurisdiction to all official state religions-Protestant, Catholic, and Hindu-Buddhist. However, religious discrimination still exists, because, as Clifford Geertz says, "for all intents and purposes a santri affair from top to bottom." 38 In short, the Religion Department has to be eliminated because of the religious discrimination it causes, and particularly because of the state's involvement in the internal affairs of religion.

The state's concession on Islam as a majority religion demanding privileges naturally causes a discrimination against other religions. The implementation of exclusive, discriminative regulations that deny the Pancasila spirit is closely related to the conspiracy between a religion that demands dominion over others and a state that wants to maintain its power. Discriminative laws such as the Joint-Decision (Surat Keputusan Bersama, SKB) of the Minister of Religion and the Minister of Home Affairs No.01/BER/MDM-MAG/1969 regarding the building of houses of worship, now renewed as Joint-Regulation (Peraturan Bersama, Perber) of Two Ministers 2006 are the results of a conspiracy between Islam and the state. The implementation of those discriminative rules, in spite of its ineffectiveness, is still forced on.

The National Education Law 1989, renewed to become the National Education Laws System (UU Sisdiknas), has been admitted to be advantageous to Islam. The same happens to the marriage law. The arrests of people charged with converting individuals from other religions to a certain religion are evidence that the continuing privatization of religion in this reformation era has a negative impact. At present, even religion criminalization which jeopardizes the harmony between religious groups

37 The most important part of the Jakarta Charter is the formulation of the first principle of Pancasila. Instead of "the Principle of One Lordship," it says: "the Principle of One Lordship with the obligation to carry out the Islamic law (Shari'ah) for its adherents."

38 Clifford Geertz, The Religion of Java (Chicago: The University of Chicago Press, 1976), p. 200. 
and has done a lot of harm will be sanctioned in the new "Proposal on Criminal Law" (RUU KUHP) by the addition of an ambiguous paragraph (pasal karet) about religion harassment.

Islam's wish to have a privileged position is also obvious from the existence of Moslem-sounding regional regulations, known as the Peraturan Daerah (Perda) Syariat (Shariah Regional Law). Perda Syariat turns up in various regions, justifying itself by claiming that the Perda Syariat is in harmony with the democratic principle. Perda Syariat has become a polemical, tough, problem, because it encourages other religions to follow in its footsteps: in Manokwari, for instance, where the majority religion is Christian, a Perda Injil (Gospel Regional Law) has been implemented. As a matter of fact, the religiously tinted Perda is contradictory to the Pancasila and the spirit of the Indonesian Constitution (UUD'45). Other religions naturally resent its presence. Moreover, the Perda reflects a strong sense of religious zeal by positioning religion as the single solution to all of the problems faced by this diverse nation.

The great advantage that Islam has gained by conspiring with the state puts other official religions into temptation. We can read about the state's conspiracy with the official state religions in the definition of religion according to the Department of Religion. The Moslem-sounding definition of religion gives Islam a great advantage, but at the same time it also gives other official religions a special place. The diverse tribal religions and mysticisms have reluctantly become a mission or propagation field for official religions. In essence, the definition of religion has become a violent act of the state towards religions, in this case minority religions like tribal religions and mysticisms. The requirements for a certain religion to become legal include: having a Holy Book, prophets, belief in the one and only personal God, international recognition, and the obligation to have a comprehensive religious law system. These requirements automatically exclude various mysticisms.

Niels Mulder observes that not a single criterion of the requirements can be fulfilled by the religious sects and mysticisms. This proves that they are the main target of those who set the criteria. ${ }^{39}$ Initially, the involvement of the santri ("devoted") Islam in the definition of religion was intended to gain control over the abangan ("nominal") Islam and to coerce them to submit to Islam as a religion. Unfortunately, many of the abangan Islam chose Christianity instead. ${ }^{40}$ Obviously, the religionization of politics has more negative impact on religion rather than gaining advantage from it. Therefore, a reexamination of the Religion Department's version concerning the criteria of religion in order to eliminate the discrimination

\footnotetext{
39 Niels Mulder, Mysticism and Everyday Life in Contemporary Java: Cultural Persistence and Change (Singapore: Singapore University Press, 1978), pp. 4-6.

40 Intan, "Public Religion" and the Pancasila-Based State of Indonesia, pp. 44-5, 50-1.
} 
against certain religious beliefs is absolutely necessary. However, it is not the main problem. The crux of the matter is whether the state is justified to define what religion is, and whether it has the authority to decide which can or cannot be called a religion.

In the course of history, the suggestion that every Indonesian must belong to a certain religion has been claimed as the legitimacy of requiring all Indonesians to belong to a certain religion, namely, the official state religions. In spite of its ambiguous legitimacy, this claim is supported by official religions. It is apparent that there has been a conspiracy to politicize state religions and religionize politics, which later on will proof disadvantageous to both sides. In this reformation era, this is noticeable at least by the increasing distrust among religions which often escalates into violence supported by people in the name of religion.

Government intervention into religion's private sphere can clearly be seen by the inclusion of the religion column on the ID card (KTP), to be filled in only with one of the six official religions according to the Religion Department version. Restraint has been put on minority religions. Tribal religions and mysticisms have been robbed of their civil rights by the designation of the official religions. This fact indicates that Indonesia is established not only as a state based on religion, but as a state that considers a non-adherence to a religion as something taboo. Worse still, religion is then restricted to the so-called official state religion. Actually, from the functional and substantial point of view of religion, no one is without a religion, although he/she claims to be non-religious. It means that religion cannot be restricted to the official religions. On the other hand, making religion compulsory causes it to lose its essence as a religion, because the realization of a divine existence cannot be coerced. It is indeed regrettable that the freedom to choose a religion, which should be a matter between God and the believer, has been taken over by the state.

The government's intervention involves the so-called heresies. Ironically, over and over again the government receives support from the official religions it has legitimized. Religious leaders are also tempted to use violence to maintain its existence. Religious violence is not only done openly by the government, but also by individuals and existing religious groups. Religion hegemony has reached the public sphere. The state not only allows it to happen, but has become the main actor in encouraging it.

When religious institutions take part in the same crime committed by the government, the problem of religion in the public sphere becomes complicated. Attempts to control riots carried out in the name of religion are often done half-heartedly. The proliferation of violence is supported by the society. During the present Indonesian reformation era, the country ranks top in church burning. Until today approximately 1500 churches have been burnt down, demolished and closed. This community-supported violence 
was not only aimed at burning and destroying churches. Other religious houses of worship, especially from minority groups such as the Ahmadiyah, Lia Eden and other mysticisms also feel threatened nowadays. The violence destroys not only possessions, but also involves killings. Tragically, nobody was even arrested or put to trial-which is strong evidence that the government looks the other way when violence in the name of religion is going on.

The tragedy of imprisoned innocent believers shows that the government never tires of hampering religious freedom. On the contrary, it has become more zealous in doing it. Religious hegemony, trying to take advantage of the chaos, has distorted the face of public religion in Indonesia.

\section{The development prospect of the "Public Religion"}

The distorted face of public religion, which has been going on since Indonesia's independence, does not need to cause too much pessimism. Religion is ambivalent: it is potentially violent on the one hand, but encouraging reconciliation on the other. The fierce face of religion is just part of the whole truth. It is publicly known that a pro-democracy religious group has played a decisive role in toppling the Suharto government. ${ }^{41}$ This gives us a valid reason that optimism towards public religion is not unrealistic. The question is, how can the presence of religion in the public sphere be "normative objective," 42 showing a conciliatory face rather than a violent one? How can it become a motivator instead of hindering democracy?

In the context of a Pancasila-based state (neither a secular nor a theocratic state), a clear relation between religion and the state determines the growth of public religion normative objectively. As mentioned above, the politicization of religion and the religionization of politics have become a main obstacle for public religion to thrive. In a Pancasila-based state, there is neither a subordination of religion by the state nor a subordination of the state by religion. A Pancasila way of thinking strives for a nonoverlapping relation between the state and religion - "a free (Religion) in a free State," as Abraham Kuyper says. ${ }^{43}$ Without a community of freedom, the politicization of religion and the religionization of politics are inevitable. However, this does not mean that religion and the state have to

41 Hefner, "Islam and Nation in the Post-Suharto Era,"in The Politics of Post-Suharto Indonesia, Adam Schwarz and Jonathan Paris, eds. (New York: Council on Foreign Relations Press, 1999), p. 45; Amien Rais, "Islam and Politics in Contemporary Indonesia," in Post-Soeharto Indonesia: Renewal or Chaos?, Geoff Forrester, ed. (New York: St. Martin's Press, 1999), p. 199.

42 Hollenbach, The global Face of Public Faith: Politics, Human Rights, and Christian Ethics (Washington, D.C.: Georgetown University Press, 2003), p. 5.

43 Abraham Kuyper, Lectures on Calvinism (Grand Rapids: William B. Eerdmans, 1931; reprint, September 1987), pp. 99, 106. 
be segregated. They are "separated but not parted" (ada pemisahan tetapi tidak ada keterpisahan). ${ }^{44}$ It means that although they are separated from each other, the state and religion have a mutual responsibility towards each other.

The issue is how to fulfill the responsibility of religion toward the state and the state's responsibility toward religion in encouraging the role of religion in the public sphere, instead of being trapped in the politicization of religion and the religionization of politics discourse?

A Pancasila-based state has the responsibility to guarantee the freedom of its citizens in practicing their religious beliefs without intervening with the internal affairs of a religion. Not only in the form of negative immunity where religion has to be freed from the bondage of social political powers such as the state, but also in a positive immunity sense where religion is encouraged to carry out its public role. In performing its religious function, boundaries have to be set for the state, as Michael Walzer says, "at" the boundaries and not "across" the boundaries of the state. ${ }^{45}$

In other words, the state should not use the protection of religion from the control of social powers or the encouragement of religion in its public function as an excuse to interfere with the internal affairs of a religion, not even under the pretext of upholding public justice, which is the state's main duty. On instances where religious teachings disturb public order, for example, the state has the right to forbid the interpretation of religion. However, it may not touch the core belief, except when the related religion is the source of the problem.

A state which offers fertile ground for public religion is a state which follows the principle of state-society distinction, where the state has to be distinguished from the society. According to this principle, the state is part of the society, but the state is not society itself. The societal community is very broad; it comprises, among others, the family as a community, religion, economics, and the state. Equalizing the state with society means making the state the sole controlling power over the res publica (public affairs). Both the Old Order and the New Order of the Indonesian government have the tendency to trivialize public religion because of the state's "integrating" concept which denies the principle of state-society distinction. As a result, the state's power spreads out to the private domain of religion. ${ }^{46}$

44 According to Eka Darmaputera, this sentence describes John Calvin's stand on the relation of religion-state. See Eka Darmaputera, "Aspek-Aspek Etis-Teologis Hubungan Gereja-Negara dan Implikasinya dalam Negara Pancasila" in Hubungan Gereja dan Negara dan Hak Asasi Manusia: Bunga Rampai Pemikiran, Weinata Sairin and J.M. Pattiasina, eds. (Jakarta: BPK Gunung Mulia, 1996), p. 19.

45 Michael Walzer, Spheres of Justice: A Defense of Pluralism and Equality (New York: Basic Books, 1983), pp. 15, 282.

46 Adnan Buyung Nasution, The Aspiration for Constitutional Government in Indonesia: A Socio- 
In the state-society distinction, each community element such as the state and religion have its own autonomy and independence. Kuyper uses the term "sphere sovereignty." ${ }^{47}$ However, sovereignty in every societal community does not justify arbitrariness over other communities which have the same interest in the public sphere. Each community in the public sphere has a certain sovereignty which is limited by the sovereignty of other communities that are also present. So, there are no ranks in the autonomy among communities. A state which respects the idea of state-society distinction will become a fertile ground for the seeds of public religion.

On the other side, without the intention to interfere with the state's internal affairs, religion has a responsibility to the state, which according to the 1998 "Guidelines of State Policy" (Garis-garis Besar Haluan Negara, GBHN) is to "continually and jointly lay a strong moral, ethical and spiritual foundation for nation building as an implementation of Pancasila." It means that the framework of moral, ethical and spiritual foundation is not the sole contribution of one religion, but has to be collectively provided by the various religions. Therefore, in their mission at the public sphere religions should neither attempt to dominate and trivialize, nor to eliminate, each other. The relation between religions should go beyond a mere peaceful coexistence. At this level religions communicate with each other but only to the extent of avoiding conflict and leaving each other in peace. There is little awareness of the interdependence between religions in fulfilling their mission in the public sphere.

An ideal relation between religions would be a creative proexistence, in which religions realize the need to care for each other because of their mutual dependence. Simatupang plainly affirms that a Pancasilabased state does not merely acknowledge the diversity of religions.

A Pancasila state does not emphasize coexistence, but also cooperation among religions based on mutual responsibility in developing culture, society and the state. ${ }^{48}$

Cooperation between religions has become a necessity, particularly by applying the Golden Rule ("do unto others what you would like them do unto you") based on the individual version of each religion.49 The application of the Golden Rule as the mutual common ground will bear pro-

\footnotetext{
Legal Study of the Indonesian Konstituante 1956-1959 (Jakarta: Pustaka Sinar Harapan, 1992), pp. 421 2; David Bourchier, "Totalitarianism and the 'National Personality:' Recent Controversy about the Philosophical Basis of the Indonesian State," in Imagining Indonesia: Cultural Politics and Political Culture, edit oleh Jim Schiller dan Barbara Martin-Schiller (Athens: Ohio University Center for International Studies, 1997), pp. 157-85.

47 Kuyper, "The Antirevolutionary Program," in Political Order and the Plural Structure of Society, James W. Skillen and Rockne M. McCarthy, eds. (Atlanta: Scholars Press, 1991), p. 242.

48 Simatupang, Iman Kristen dan Pancasila (Jakarta: BPK Gunung Mulia, 1998), hlm. 169.

49 John Hick, "A Pluralist View," in Four Views on Salvation in a Pluralistic World, Dennis L. Okholm dan Timothy R. Phillips, eds. (Grand Rapids: Zondervan Publishing House, 1996), pp. 39-40.
} 
existence as its fruit. In such a condition, passive religions should not be left dying, but has to be revived, too. In turn, they will give their contribution. In interdependence among religions, the extinction of a religion will have an impact on the genuine civil consensus it is trying to reach. If the awareness of religious interdependence keeps growing, maximizing religion in the public sphere will be achievable.

In fulfilling its responsibility to the state, religion remains at the moral political level, not in power politics. Harold Lasswell distinguishes power politics (who gets what, when and how) about power an sich from moral politics (who should get what, when and how-and why) which concerns justice. ${ }^{50}$ Religion's role is a moral political one. Striving for a democratic political life, religion fulfills its critical and prophetic function as a transforming and liberating power in society and the nation by laying a moral, ethical and spiritual foundation. Therefore, the steps taken by religion at state level to shape a theocratic state cannot be tolerated, because religion has become a standard in the state's decision making. It is not a democratic discourse because of its exclusive and discriminatory nature. It is exclusive because it treats the country's citizens according to their level of superiority, priority and majority. It is discriminatory because it makes distinctions between citizens. Those are also the consequences of religions disputing at political society level, for instance by establishing a political party. Such discourse will not empower democracy in religion because of its exclusivity. In this discourse, religious symbols are engaged in satisfying the social-political needs of religion.

According to Casanova's analysis, religion has become a motivator of democracy at civil society level. ${ }^{51}$ The starting point of "public religion" in this discourse is the fact of the nation's diversity. "Public religion" utilizes the potential power of religions in answering the concrete challenge of humanity in society. It is not about dominion among religious groups, but more about brainstorming on how religions can play the role of a democratic power in transforming society's social-political life. The goal is how to make the nation's political life more moralistic and ethical. Religions' morality ought to enlighten and stimulate the nation's political life so that political decision-making becomes morally reliable. Only a religion which is true to moral politics at civil society level will have the liberating strength to generate a democratic political life.

50 Daniel J. Elazar, Covenant and Polity in Biblical Israel: Biblical Foundations and Jewish Expressions, Volume I of the Covenant Tradition in Politics (New Brunswick: Transaction Publishers, 1998), p. 2.

51 Casanova, Public Religions in the Modern World, pp. 218-220. 


\section{Conclusion}

It is depressing to see the face of public religion continuously scarred by conflicts that should not have happened. After all, religions in Indonesia have played a significant role in presenting a friendly and hospitable Indonesian community, well-known all over the world. This country's history has shown that a pessimism regarding public religion turns out to be very unproductive and will cause deeper scars. As the diverse religions of Indonesia are peaceful religions and had in the past rendered meaningful contributions to the development of the nation, an optimistic attitude for public religion is a necessity.

An optimism is in this case not a utopia because Indonesia possesses ample resources, not only historically but also in the legitimacy of its Constitution as reflected by the five principles of the Pancasila. It is undeniable that the trauma that the totalitarian system of the New Order has caused and which has spread within the entire private sphere is still felt by the nation. Nevertheless, another danger that threatens the wholeness of the country looms large, namely, a religious dominion that ambitiously seeks to have control over the public sphere. At present that danger is increasingly apparent in Indonesia and is likely to escalate into tragedy if we are slow to realize that religions should be appropriately re-positioned in the public sphere.

\section{BIBLIOGRAPHY}

Alexis de Tocqueville. Democracy in America. New York: Everyman's Library, 1994.

Appleby, R. Scott. The Ambivalence of the Sacred: Religion, Violence, and Reconciliation. Lanham: Rowman \& Littlefield Publishers, Inc., 2000.

Berger, Peter L. Protestantism and the Quest for Certainty, Christian Century 115, no. 23. 1998

Berger, Peter L. "The Desecularization of the World: A Global Overview", in The Desecularization of the World: Resurgent Religion and World Politics. Peter L. Berger, ed. Washington D.C. and Grand Rapids: Ethics and Public Policy Center and William B. Eerdmans, 1999.

Bourchier, David. "Totalitarianism and the 'National Personality:' Recent Controversy about the Philosophical Basis of the Indonesian State", in Imagining Indonesia: Cultural Politics and Political Culture. Jim Schiller and Barbara Martin-Schiller, eds. Athens: Ohio University Center for International Studies, 1997.

Casanova, Jose. Public Religions in the Modern World. United States of America: University of Chicago Press, 1994 
Darmaputera, Eka. "Aspek-Aspek Etis-Teologis Hubungan Gereja-Negara dan Implikasinya dalam Negara Pancasila", in Hubungan Gereja dan Negara dan Hak Asasi Manusia: Bunga Rampai Pemikiran. Weinata Sairin and J.M. Pattiasina, eds. Jakarta: BPK Gunung Mulia, 1996.

Djiwandono, J. Soedjati, Setengah Abad Negara Pancasila: Tinjauan Kritis

Ke Arah Pembaruan. Jakarta: Centre for Strategic and International Studies, 1995.

Elazar, Daniel J. Covenant and Polity in Biblical Israel: Biblical Foundations and Jewish Expressions, Volume I of the Covenant Tradition in Politics. New Brunswick: Transaction Publishers, 1998.

Everett, William Johnson. God's Federal Republic: Reconstructing Our Governing Symbol. New York: Paulist Press, 1988.

Everett, William Johnson. Religion, Federalism, and the Struggle for Public Life: Cases from Germany, India, and America. New York: Oxford University Press, 1997.

Fukuyama, Francis. The End of History and the Last Man. New York: Avon Books, 1992.

Geertz, Clifford. The Religion of Java. Chicago: The University of Chicago Press, 1976.

Hefner, Robert W. "Islam and Nation in the Post-Suharto Era", in The Politics of Post-Suharto Indonesia. Adam Schwarz and Jonathan Paris, eds. New York: Council on Foreign Relations Press, 1999.

Hefner, Robert W. "Islamizing Java? Religion and Politics, in Rural East Java", Journal of Asian Studies 46. 1987.

Hick, John. "A Pluralist View", in Four Views on Salvation in a Pluralistic World. Dennis L. Okholm dan Timothy R. Phillips, eds. Grand Rapids: Zondervan Publishing House, 1996.

Hollenbach, David. "Politically Active Churches: Some Empirical Prolegomena to a Normative Approach", in Religion and Contemporary Liberalism. Paul J. Weithman, ed. Notre Dame: University of Notre Dame Press, 1997.

Hollenbach, David. "Fidelity to the Gospel/Respect for the Other", in Faith in the Public Forum. Neil Brown and Robert Gascoigne, eds. Adelaide: Australian Theological Forum, 1999.

Hollenbach, David. Public Reason/Private Religion? A Response to Paul J. Weithman, Journal of Religious Ethics 22, no. 1. 1994

Hollenbach, David. The global Face of Public Faith: Politics, Human Rights, and Christian Ethics. Washington, D.C.: Georgetown University Press, 2003.

Intan, Benyamin F, ed. God's Fiery Challenger for Our Time. Jakarta: STEMI and Reformed Center for Religion and Society, 2007

Intan, Benyamin F, ed. Reform Review: Jurnal untuk Kajian dan Pemetaan Krisis Vol. I, no. 1. Jakarta: STEMI and Reformed Center for 
Religion and Society. April-June 2007.

Intan, Benyamin F. Public Religion and the Pancasila-Based State of Indonesia. American University Studies: Theology and Religion, 2006.

Johnston, Douglas and Cynthia Sampson, eds. Religion, the Missing Dimension of Statecraft. New York and Oxford: Oxford University Press, 1994.

Juergensmeyer, Mark. The New Cold War? Religious Nationalism Confronts the Secular State. Berkeley and Los Angeles: University of California Press, 1994.

Kepel, Gilles. The Revenge of God: The Resurgence of Islam, Christianity and Judaism in the Modern World. University Park: The Pennsylvania State University Press, 1994.

Kuyper, Abraham. Lectures on Calvinism. Grand Rapids: William B. Eerdmans, 1931; reprint, September 1987.

Kuyper, Abraham. "The Antirevolutionary Program", in Political Order and the Plural Structure of Society. James W. Skillen and Rockne M. McCarthy, eds. Atlanta: Scholars Press, 1991.

Luckmann, Thomas. The Invisible Religion: The Problem of Religion in Modern Society. New York: Macmillan, 1967.

Luhmann, Niklas. The Differentiation of Society, trans. Stephen Holmes and Charles Larmore. New York: Columbia University Press, 1982.

Mulder, Niels. Mysticism and Everyday Life in Contemporary Java: Cultural Persistence and Change. Singapore: Singapore University Press, 1978.

Nasution, Adnan Buyung. The Aspiration for Constitutional Government in Indonesia: A Socio-Legal Study of the Indonesian Konstituante 19561959. Jakarta: Pustaka Sinar Harapan, 1992.

Rais, Amien. "Islam and Politics in Contemporary Indonesia", in PostSoeharto Indonesia: Renewal or Chaos?. Geoff Forrester, ed. New York: St. Martin's Press, 1999.

Rawls, John. The Idea of an Overlapping Consensus, Oxford Journal of Legal Studies 7. 1987

Simatupang, T.B. Iman Kristen dan Pancasila. Jakarta: BPK Gunung Mulia, 1998.

Simatupang, T.B. Membuktikan Ketidakbenaran Suatu Mitos: Menelusuri Makna Pengalaman Seorang Prajurit Generasi Pembebas Bagi Masa Depan Masyarakat, Bangsa dan Negara. Jakarta: Pustaka Sinar Harapan, 1991.

Stark, Rodney dan Roger Finke. Acts of Faith: Explaining the Human Side of Religion. Berkeley: University of California Press, 2000.

Verkuyl J. Contemporary Mission: An Introduction. Grand Rapids: William B. Eerdmans, 1987. 
Walzer, Michael. Spheres of Justice: A Defense of Pluralism and Equality. New York: Basic Books, 1983.

Whaling, Frank, ed. Religion in Today's World: The Religious Situation of the World from 1945 to the Present Day. Edinburgh: T \& T Clark, 1987. 